\title{
PERTUMBUHAN TANAMAN BAYAM CABUT (Amaranthus tricolor L.) DENGAN PEMBERIAN KOMPOS BERBAHAN DASAR DAUN KRINYU \\ (Chromolaena odorata L.)
}

\author{
Puja Kesuma, Zuchrotus Salamah
}

\begin{abstract}
ABSTRAK
$\mathrm{P}$ enelitian ini bertujuan untuk mengetahui: pertumbuhan tanaman bayam cabut ( $\mathrm{Ama}$ ranthus tricolor L.) yang diberi perlakuan dengan pemberian kompos berbahan dasar daun krinyu (Chromolaena odorata L.), dan untuk mengetahui komposisi kompos berbahan dasar daun krinyu (Chromolaena odorata L.) dan tanah yang efektif terhadap pertumbuhan tanaman bayam cabut (Amaranthus tricolor L.).Penelitian ini menggunakan rancangan acak lengkap (RAL) dengan 6 perlakuan antara lain : K : kontrol (tanpa kompos) dan 2,5 kg tanah, A1: kompos 0,125 kg dan tanah 2,375 kg, A2:kompos 0,25 kg dan 2,25 kg tanah, A3: kompos 0,5 $\mathrm{kg}$ dan $2 \mathrm{~kg}$ tanah, A4:kompos 0,75 $\mathrm{kg}$ dan 1,75 $\mathrm{kg}$ tanah, A5:kompos $1 \mathrm{~kg}$ dan 1,5 $\mathrm{kg}$ tanah. Selanjutnya data dianalisis menggunakan analisis varian (ANAVA). Apabila terdapat beda nyata, maka dilanjutkan dengan uji BNT dengan taraf 5\%. Hasil penelitian diperoleh bahwa pertumbuhan bayam cabut (Amaranthus tricolor L.) dengan pemberian kompos berbahan dasar daun krinyu (Chromolaena odorata L.) menunjukkan hasil yang baik dan komposisi pemberian pupuk kompos berbahan dasar daun krinyu (Chromolaena odorata L.) dan tanah yang efektif untuk pertambahan bayam cabut (Amaranthus tricolor L.) adalah pada perlakuan A2 (Komposisi kompos 0,25 kg dan tanah 2,25 kg). Hasil penelitian ini diharapkan dapat diterapkan langsung sebagai alternatif sumber belajar Biologi SMA kelas XII pada materi pembelajaran pertumbuhan pada tumbuhan dalam bentuk power point.
\end{abstract}

Kata kunci : pertumbuhan, bayam cabut (Amaranthus tricolor L.), dan kompos daun krinyu (Chromolaena odorata L.). 


\section{PENDAHULUAN}

Tanaman bayam cabut merupakan tanaman yang sangat dibutuhkan masyarakat mengingat fungsinya sebagai pemenuh kebutuhan gizi masyarakat karena mengandung zat gizi antara lain: protein, karbohidrat, lemak, zat besi vitamin A, B, C serta serat (Rukmana, 2010), sehingga perlu dilakukan peningkatan produksi untuk mencukupi kebutuhan gizi masyarakat.

Peningkatan produksi bayam cabut dapat dilakukan dengan cara penambahan unsur hara pada lahan pertanian. Unsur hara dapat diperoleh dengan cara pemupukan. Pemupukan merupakan suatu usaha penambahan unsur hara dalam tanah yang dapat meningkatkan kesuburan dan produksi tanaman (Irwanto, 2010). Pupuk yang dapat ditambahkan bisa berupa pupuk anorganik dan organik. Namun, penggunaan pupuk anorganik yang terus menerus akan berdampak negatif terhadap produktivitas tanah dan lama-kelamaan akan menjadi keras (Simaora dan Salundik, 2006). Kesuburan dan kegemburan tanah akan terjaga jika menambahkan bahan organik, salah satunya adalah kompos.

Kompos dapat dibuat dari jerami, sampah rumah tangga dan daun-daunan salah satunya adalah daun krinyu. Kompos krinyu (Chromolaena odorata L.) berasal dari tumbuhan gulma tahunan yang meru- gikan karena kandungan nitrat yang tinggi dapat menyebabkan keracunan bahkan kematian ternak (Prawiradiputra, 2007). Selain merugikan, krinyu ini mengandung unsur hara yang tinggi yakni $2,42 \% \mathrm{~N}, 0,26 \% \mathrm{P}$ dan 1,6\% K (Suntoro dalam Kastono, 2005) yang dapat menyuburkan tanaman serta diharapkan mampu meningkatkan pertumbuhan bayam cabut.

Penelitian ini bertujuan untuk mengetahui bagaimanakah pertumbuhan tanaman bayam cabut (Amaranthus tricolor L.) dengan pemberian komposisi pupuk kompos berbahan dasar daun krinyu (Chromolaena odorata L.) dan tanah serta berapakah komposisi pemberian pupuk kompos berbahan dasar daun krinyu (Chromolaena odorata L.) dan tanah yang paling efektif terhadap pertumbuhan tanaman bayam cabut (Amaranthus tricolor L.). Hasil penelitian ini dapat dimanfaatkan dalam materi pembelajaran pertumbuhan pada tumbuhan, sehingga hasil penelitian ini diharapkan dapat digunakan sebagai alternatif sumber belajar biologi SMA kelas XII pada materi pembelajaran pertumbuhan pada tumbuhan. 


\section{BAHAN DAN METODE}

Percobaan ini dilakukan di Glagah Sari, Yogyakarta dan di Laboratorium Biologi Universitas Ahmad Dahlan pada bulan Maret-April 2012. Rancangan percobaan yang dipergunakan dalam penelitian ini adalah Rancangan Acak lengkap (RAL) dengan satu faktor yaitu perlakuan pemberian kompos berbahan dasar daun krinyu (Chromolaena odorata L.) dengan komposisi :

K0 : Kontrol (2,5 kg tanah)

A1: $0,125 \mathrm{~kg}$ kompos dan 2,375 $\mathrm{kg}$ tanah

A2: $0,25 \mathrm{~kg}$ kompos dan 2,25 kg tanah

A3: $0,5 \mathrm{~kg}$, kompos dan $2 \mathrm{~kg}$ tanah A4: $0,75 \mathrm{~kg}$ Kompos dan 1,75 kg tanah A5: $1 \mathrm{~kg}$ kompos dan 1,5 $\mathrm{kg}$ tanah

Masing-masing perlakuan 4 kali ulangan dengan parameter pertumbuhan yakni tinggi tanaman, jumlah dauan, panjang daun, diameter batang berat basah dan kering tanaman. Data hasil penelitian dianalisis dengan menggunakan metode analisis varian (ANAVA) untuk mengetahui perbedaan perlakuan dan apabila terdapat perbedaan nyata dilanjutkan dengan uji BNT 5\%.

\section{HASIL DAN PEMBAHASAN}

\section{A. Analisis Pupuk Kompos}

Hasil analisis kandungan unsur yang terdapat dalam kompos berbahan dasar daun krinyu (Chromolaena odorata L.) adalah 2,10\% N (Nitrogen), 0,18\% P (Fosfor), 18,77\% K (Kalium) dan 59,19\% kadar air (BBTKL, 2012).

\section{Tinggi Tanaman Bayam Cabut (Am- aranthus tricolor $L$.)}

Rerata tinggi tanaman bayam cabut (Amaranthus tricolor L.) dapat dilihat pada Tabel 1. berikut:

\begin{tabular}{|c|c|c|c|c|}
\hline \multirow{2}{*}{$\begin{array}{c}\text { Per- } \\
\text { lakuan }\end{array}$} & \multicolumn{4}{|c|}{ Rerata Tinggi Tanaman (Cm) } \\
\cline { 2 - 5 } & \multicolumn{4}{|c|}{ Umut Tanaman (Minggu) } \\
\cline { 2 - 5 } & 1 & 2 & 3 & 4 \\
\hline $\mathrm{K}_{0}$ & 6,72 & 10,77 & 28,05 & 42,87 \\
\hline $\mathrm{A}_{1}$ & 7,85 & 14,00 & 35,05 & 51,87 \\
\hline $\mathrm{A}_{2}$ & 8,12 & 15,50 & 42,87 & 63,50 \\
\hline $\mathrm{A}_{3}$ & 7,97 & 14,95 & 39,12 & 59,87 \\
\hline $\mathrm{A}_{4}$ & 7,12 & 14,75 & 37,50 & 57,25 \\
\hline $\mathrm{A}_{5}$ & 6,87 & 13,42 & 32,92 & 48,87 \\
\hline
\end{tabular}

Tabel 1. Rerata Tinggi Tanaman Bayam Cabut Umur 1-4 Minggu

Keterangan:

$\mathrm{K} 0=\mathrm{Kontrol}(2,5 \mathrm{Kg}$ tanah $)$

$\mathrm{A} 1=$ Kompos $0,125 \mathrm{~kg}$,tanah $2,375 \mathrm{Kg}$

$\mathrm{A} 2=$ Kompos $0,25 \mathrm{~kg}$, tanah 2,25 Kg

$\mathrm{A} 3=$ Kompos $0,5 \mathrm{Kg}$, tanah $2 \mathrm{Kg}$

A4 $=$ Kompos $0,75 \mathrm{Kg}$,tanah $1,75 \mathrm{Kg}$

A5 $=$ Kompos 1,0 kg,tanah 1,5 Kg

Berdasarkan Tabel 1., dapat dibuat grafik tinggi tanaman bayam cabut sebagai berikut :

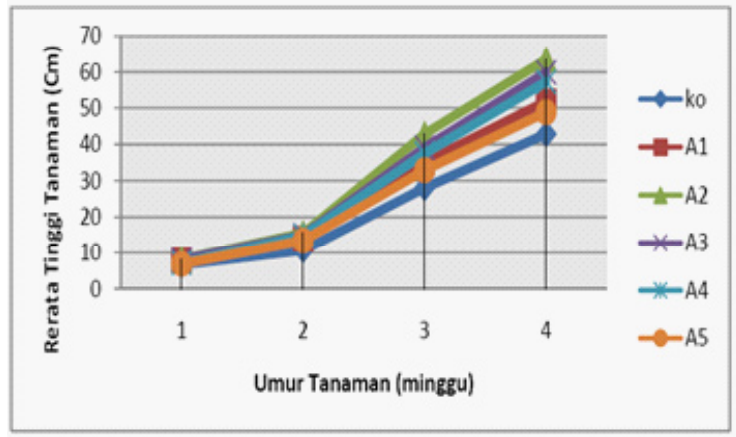

Grafik 1. Tinggi Tanaman Bayam Cabut Umur 1-4 Minggu dengan Berbagai Perlakuan 
Perlakuan A2 (kompos) 0,25 kg dan tanah 2,25 kg menunjukkan rerata tinggi tanaman yang paling baik yaitu $63,50 \mathrm{~cm}$, hal ini dipengaruhi oleh kandungan unsur nitrogen yang diperoleh dari pemberian kompos berbahan dasar daun krinyu.

Menurut Lingga dan Marsono (2008) peran utama nitrogen bagi tanaman adalah yakni meningkatkan pertumbuhan bagian vegetatif tanaman yakni pertumbuhan organ akar, batang dan daun. Adapun hasil uji kompos daun krinyu mengandung unsur $\mathrm{N}$ sebesar 2,10\%. Selain mengandung N kompos daun krinyu juga mengandung unsur $\mathrm{K}$ sebesar $18,77 \%$.

Menurut Simamora dan Salundik (2006) unsur K ini berfungsi untuk memperkuat jaringan tanaman, selain itu juga berfungsi untuk mengatur berbagai proses fisiologi tanaman seperti mengatur kondisi air di dalam sel dan jaringan. Jika air dan unsur hara terpenuhi maka pembelahan di ujung meristem dapat bekerja dengan baik dan berdampak pada perolehan tinggi tanaman.

Menurut Lakitan (1996) terjadinya pertambahan tinggi tanaman karena adanya sel-sel meristem apikal yang selalu membelah. Pembelahan sel yang dihasilkan dari pembelahan sel dapat menyebabkan pertambahan ukuran tanaman.
2. Jumlah Daun Tanaman Bayam

\section{Cabut (Amaranthus tricolor L.)}

Rerata jumlah daun tanaman bayam cabut (Amaranthus tricolor L.) dapat dilihat pada Tabel 2. Berikut.

\begin{tabular}{|c|c|c|c|c|}
\hline \multirow{3}{*}{ Perlakuan } & \multicolumn{4}{|c|}{ Rerata Jumlah daun tanaman (helai) } \\
\cline { 2 - 5 } & \multicolumn{4}{|c|}{ Umur tanaman } \\
\cline { 2 - 5 } & 1 & 2 & 3 & 4 \\
\hline $\mathrm{K}_{0}$ & 3,50 & 4,75 & 7,25 & 8,50 \\
\hline $\mathrm{A}_{1}$ & 3,00 & 4,25 & 8,75 & 10,00 \\
\hline $\mathrm{A}_{2}$ & 4,75 & 6,50 & 10,75 & 13,00 \\
\hline $\mathrm{A}_{3}$ & 3,75 & 5,75 & 9,25 & 11,25 \\
\hline $\mathrm{A}_{4}$ & 4,00 & 5,25 & 9,00 & 10,50 \\
\hline $\mathrm{A}_{5}$ & 4,75 & 6,00 & 8,25 & 9,75 \\
\hline
\end{tabular}

\section{Tabel 2. Rerata Jumlah Daun Tanaman Bayam Cabut Umur 1-4 Minggu}

Keterangan:

$\mathrm{K} 0=\mathrm{Kontrol}(2,5 \mathrm{Kg}$ tanah $)$

$\mathrm{A} 1=$ Kompos $0,125 \mathrm{~kg}$,tanah 2,375 Kg

$\mathrm{A} 2=$ Kompos $0,25 \mathrm{~kg}$, tanah 2,25 Kg

A3=Kompos 0,5 Kg, tanah $2 \mathrm{Kg}$

A4= Kompos $0,75 \mathrm{Kg}$,tanah $1,75 \mathrm{Kg}$

$\mathrm{A} 5=\mathrm{Kompos} 1,0 \mathrm{~kg}$,tanah 1,5 Kg

Berdasarkan Tabel 2., dapat dibuat grafik jumlah daun tanaman bayam cabut sebagai berikut:

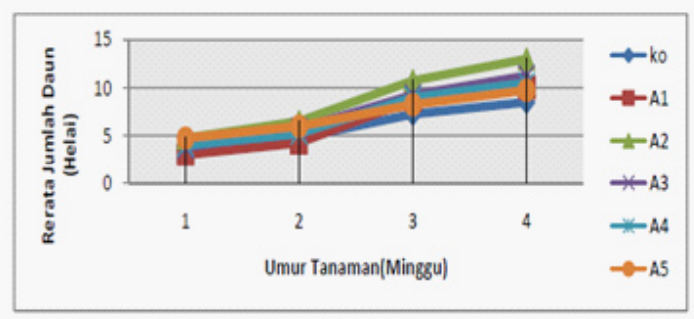

\section{Grafik 2. Jumlah Daun Tanaman Bayam Cabut Umur 1-4 Minggu dengan Berbagai Perlakuan}

Komposisi pupuk kompos berbahan dasar daun krinyu pada perlakuan A2 (Kompos $0,25 \mathrm{Kg}$ dan tanah $2,25 \mathrm{Kg}$ ) memberikan hasil yang paling baik dibandingkan 
dengan perlakuan yang lain. Hal ini disebabkan karena pada perlakuan A2 (Kompos $0,25 \mathrm{Kg}$ dan tanah 2,25 $\mathrm{Kg}$ ) mengandung unsur hara nitrogen dan kalium yang cukup untuk merangsang pertumbuhan daun, dimana unsur nitrogen dan kalium menurut Lingga dan Marsono (2008) berfungsi untuk merangsang pertumbuhan daun serta berperan untuk memperkuat daun agar tidak gugur. Berdasarkan hasil uji analisis kompos daun krinyu mengandung $\mathrm{N}$ sebesar $2,10 \%$ dan $\mathrm{K}$ sebesar $18,77 \%$.

Daun merupakan organ yang sangat penting bagi tanaman yakni sebagai tempat untuk fotosintesis. Jumlah daun yang banyak menyebabkan fotosintesis menjadi lancar. Unsur nitrogen yang terdapat di dalam pupuk kompos berbahan dasar daun krinyu menyebabkan daun menjadi lebih besar dan berwarna hijau. Unsur magnesium merupakan unsur hara makro yang diperlukan tanaman sebagai unsur pembentuk klorofil. Pada perlakuan kontrol (tanpa kompos ) dimana rerata jumlah daun semakin menurun, hal ini disebabkan karena sedikitnya jumlah air dan unsur hara yang diserap sehingga dapat menghambat proses fotosintesis dan transpirasi daun, hal ini akan berakibat pada penurunan jumlah daun.

\section{Panjang Daun Tanaman Bayam Cabut (Amaranthus tricolor L.)}

Rerata panjang daun tanaman bayam cabut (Amaranthus tricolor L.) dapat dilihat pada Tabel 3 berikut:

\begin{tabular}{|c|c|c|c|c|}
\hline \multirow{2}{*}{ Perlakuan } & \multicolumn{4}{|c|}{ Rerata Panjang daun tanaman (cm) } \\
\cline { 2 - 5 } & \multicolumn{4}{|c|}{ Umur tanaman (Minggu) } \\
\cline { 2 - 5 } & 1 & 2 & 3 & 4 \\
\hline $\mathrm{K}_{0}$ & 3,05 & 8,25 & 11,00 & 12,56 \\
\hline $\mathrm{A}_{1}$ & 3,05 & 7,87 & 12,00 & 14,31 \\
\hline $\mathrm{A}_{2}$ & 3,17 & 9,50 & 15,36 & 17,06 \\
\hline $\mathrm{A}_{3}$ & 3,10 & 8,87 & 14,50 & 15,50 \\
\hline $\mathrm{A}_{4}$ & 3,11 & 8,31 & 13,43 & 14,75 \\
\hline $\mathrm{A}_{5}$ & 2,78 & 5,31 & 11,56 & 12,75 \\
\hline
\end{tabular}

Tabel 3. Rerata Panjang Daun Tanaman

Bayam Cabut Umur 1-4 Minggu

Keterangan:

$\mathrm{K} 0=\mathrm{Kontrol}(2,5 \mathrm{Kg}$ tanah $)$

$\mathrm{A} 1=$ Kompos $0,125 \mathrm{~kg}$, tanah 2,375 Kg

$\mathrm{A} 2=$ Kompos $0,25 \mathrm{~kg}$, tanah $2,25 \mathrm{Kg}$

A3 =Kompos 0,5 Kg, tanah $2 \mathrm{Kg}$

A4 $=$ Kompos $0,75 \mathrm{Kg}$,tanah $1,75 \mathrm{Kg}$

A5 = Kompos $1,0 \mathrm{~kg}$,tanah $1,5 \mathrm{Kg}$

Berdasarkan Tabel 3., dapat dibuat grafik panjang daun tanaman bayam cabut (Amaranthus tricolor L.) sebagai berikut:

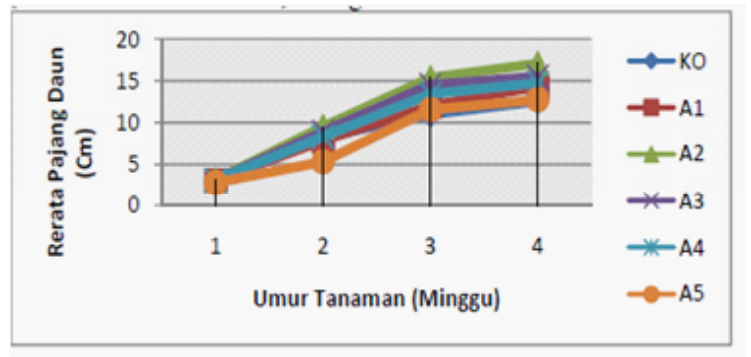

\section{Grafik 3. Panjang Daun Tanaman Bayam Cabut Umur 1-4 Minggu dengan Berbagai Perlakuan}

Pada perlakuan kontrol menunjukkan hasil rerata panjang daun paling rendah, ini berarti perlakuan kontrol yang terdiri dari tanah saja kekurangan unsur hara. Tanaman jika kekurangan maupun kelebihan unsur hara tidak baik karena setiap tanaman membutuhkan unsur hara yang sesuai dengan jumlah/takaran bagi tana- 
man tersebut.

Unsur N sangat berpengaruh terhadap pertumbuhan organ vegetatif dalam hai ini adalah daun, unsur ini mempunyai pengaruh terhadap panjang daun. Adapun hasil uji kompos daun krinyu mengandung unsur $\mathrm{N}$ sebesar 2,10\%.

\section{Diameter Batang Tanaman Bayam Cabut (Amaranthus tricolor L.)}

Hasil perhitungan rata-rata diameter batang tanaman bayam cabut (Amaranthus tricolor L.) dengan pemberian kompos berbahan dasar daun krinyu dapat dilihat pada Tabel 4 . berikut:

\begin{tabular}{|c|c|c|c|c|c|}
\hline \multirow{2}{*}{ perlakuan } & \multicolumn{4}{|c|}{ Diameter batang tanaman $(\mathrm{Cm})$} & \multirow{2}{*}{$\begin{array}{c}\text { Rata- } \\
\text { Rata }\end{array}$} \\
\cline { 2 - 5 } & 1 & 2 & 3 & 4 & \\
\hline $\mathrm{K}_{0}$ & 0,99 & 1,27 & 0,95 & 0,79 & 0,99 \\
\hline $\mathrm{A}_{1}$ & 1,05 & 1,24 & 1,52 & 1,36 & 1,29 \\
\hline $\mathrm{A}_{2}$ & 1,59 & 1,75 & 1,49 & 1,43 & 1,56 \\
\hline $\mathrm{A}_{3}$ & 1,46 & 1,17 & 1,65 & 1,33 & 1,40 \\
\hline $\mathrm{A}_{4}$ & 1,43 & 1,08 & 1,40 & 1,43 & 1,33 \\
\hline $\mathrm{A}_{5}$ & 0,89 & 0,89 & 1,43 & 1,11 & 1,08 \\
\hline
\end{tabular}

Tabel 4. Rerata Diameter Batang Tanaman Bayam Cabut Umur 1-4 Minggu

Keterangan:

$\mathrm{K} 0=\mathrm{Kontrol}(2,5 \mathrm{Kg}$ tanah $)$

$\mathrm{A} 1=$ Kompos 0,125 kg ,tanah 2,375 Kg

A2 $=$ Kompos 0,25 kg, tanah 2,25 Kg

A3=Kompos 0,5 Kg, tanah $2 \mathrm{Kg}$

A4= Kompos 0,75 Kg,tanah 1,75 Kg

A5 $=$ Kompos $1,0 \mathrm{~kg}$, tanah 1,5 Kg

Berdasarkan Tabel 4, dapat dibuat grafik rerata diameter batang tanaman bayam cabut (Amaranthus tricolor L.) sebagai berikut:

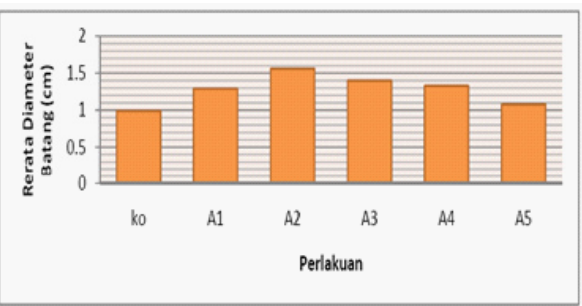

\section{Grafik 4. Rerata Diameter Batang Tanaman Bayam Cabut Umur 1-4 Minggu dengan Berbagai Perlakuan}

Pada perlakuan A2 (kompos 0,25 kg dan tanah 2,25 Kg) merupakan rerata diameter paling besar yakni $1,56 \mathrm{~cm}$. Penelitian mengenai diameter batang umumnya dapat digunakan sebagai indikator pertumbuhan untuk menjelaskan proses pertumbuhan awal sehubungan dengan pengangkutan unsur hara dari dalam tanah ataupun hasil fotosintesis.

Dalam hal ini unsur hara yang berperan adalah kalsium $(\mathrm{Ca})$ yang berfungsi untuk mengatur penyerapan air dan pengangkutan unsur hara dari dalam tanah, jika penyerapan dan pengangkutan unsur hara serta hasil fotosintesis keseluruh bagian tanaman terdistribusi dengan baik maka organ-organ tanaman akan tumbuh dengan baik, seperti organ batang, jika batang terpenuhi kebutuhan unsur hara dan air maka batang akan tumbuh besar dan diameternya akan bertambah besar juga.

\section{Berat basah Tanaman Bayam Cabut (Amaranthus tricolor L.)}

Hasil perhitungan terhadap rerata berat basah tanaman bayam cabut (Amaranthus tricolor L.) dapat dilihat pada Tabel 5. berikut: 


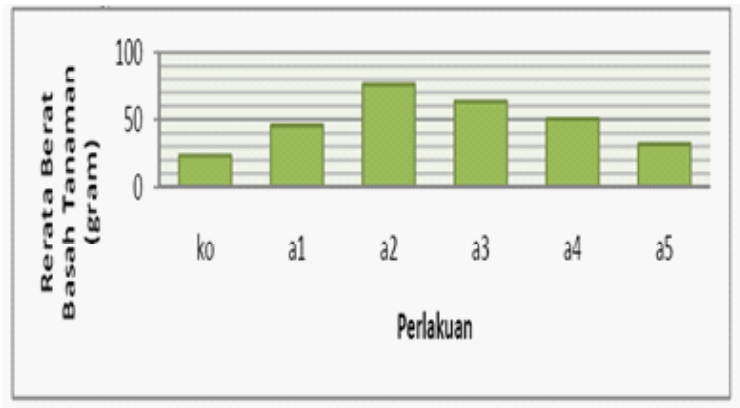

Grafik 5. Rerata Berat Basah Tanaman Bayam Cabut Umur 1-4 Minggu dengan Berbagai Perlakuan

Berat basah tanaman bayam cabut pada perlakuan A2 (kompos $0,25 \mathrm{~kg}$ dan tanah 2,25 kg) menunjukkan hasil yang paling baik yaitu 76,05 gram, hal ini disebabkan karena pada pengukuran parameter pertumbuhan yang lain seperti tinggi tanaman, jumlah daun, panjang daun dan diameter batang menunjukkan hasil yang lebih optimal dibandingkan dengan perlakuan yang lain, sehingga menyebabkan berat basah akhir tanaman bayam cabut setelah pemanenen akan optimal juga.

Berat basah tanaman menurut Lakitan (1996), merupakan berat segar tanaman pada saat tanaman masih hidup dan ditimbang secara langsung sesaat setelah dipanen, sebelum tanaman menjadi layu akibat kehilangan air. Berat basah tanaman berkurang pada siang hari karena laju transpirasi meningkat sehingga kadar air menurun.

\section{Berat kering Tanaman Bayam Cabut (Amaranthus tricolor L.)}

Hasil perhitungan terhadap rerata berat kering tanaman bayam cabut (Amaranthus tricolor L.) dapat dilihat pada Tabel 6 . JURNAL BIOEDUKATIKA

erikut:

\begin{tabular}{|c|c|c|c|c|c|}
\hline \multirow{2}{*}{ perlakuan } & \multicolumn{4}{|c|}{ Berat kering tanaman (gram) } & \multirow{2}{*}{$\begin{array}{c}\text { Rata- } \\
\text { Rata }\end{array}$} \\
\cline { 2 - 5 } & \multicolumn{4}{|c|}{ Ulangan } & \\
\cline { 2 - 5 } & 1 & 2 & 3 & 4 & \\
\hline $\mathrm{K}_{0}$ & 3,87 & 2,20 & 1,50 & 1,50 & 2,26 \\
\hline $\mathrm{A}_{1}$ & 4,60 & 3,50 & 3,15 & 4,90 & 4,03 \\
\hline $\mathrm{A}_{2}$ & 8,02 & 6,64 & 6,40 & 6,05 & 6,77 \\
\hline $\mathrm{A}_{3}$ & 5,38 & 6,05 & 4,10 & 6,19 & 5,43 \\
\hline $\mathrm{A}_{4}$ & 7,90 & 5,10 & 3,70 & 4,70 & 5,35 \\
\hline $\mathrm{A}_{5}$ & 6,50 & 1,90 & 4,19 & 2,14 & 3,68 \\
\hline
\end{tabular}

Tabel 6. Rerata Berat Kering Tanaman Bayam Cabut Umur 1-4 Minggu

Keterangan:

$\mathrm{K} 0=\mathrm{Kontrol}(2,5 \mathrm{Kg}$ tanah $)$

$\mathrm{A} 1=$ Kompos $0,125 \mathrm{~kg}$, tanah 2,375 Kg

$\mathrm{A} 2=$ Kompos 0,25 kg, tanah 2,25 Kg

A3=Kompos 0,5 Kg, tanah $2 \mathrm{Kg}$

A4= Kompos 0,75 Kg,tanah 1,75 Kg

A5= Kompos 1,0 kg,tanah 1,5 Kg

Berdasarkan Tabel 6, dapat dibuat grafik rerata berat kering tanaman bayam cabut (Amaranthus tricolor L.) sebagai berikut:

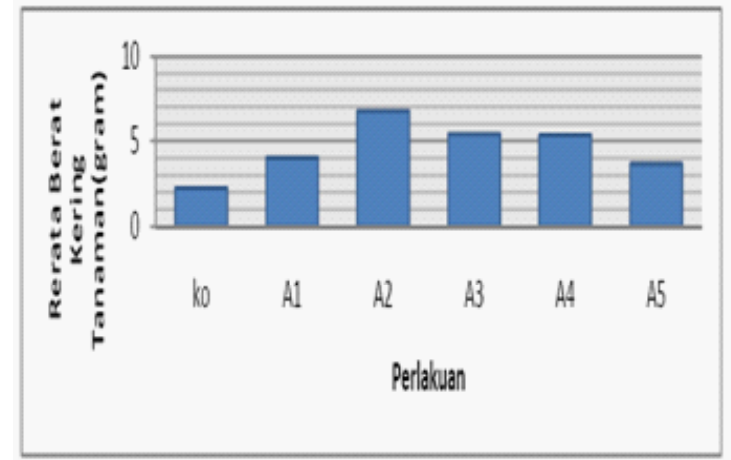

Grafik 6. Rerata Berat Kering Tanaman Bayam Cabut Umur 1-4 Minggu dengan Berbagai Perlakuan

Pengukuran berat kering dilakukan setelah panen, yaitu setelah tanaman dicabut dan dibersihkan kemudian dioven selama $3 \mathrm{x}$ 24 jam pada suhu 800C. Pengeringan dihentikan pada saat berat kering tanaman sudah 
stabil. Rerata berat kering tanaman pada perlakuan A2 (kompos 0,25 kg dan tanah 2,25 $\mathrm{kg}$ ), menunjukkan hasil yang paling baik yaitu 6,77 gram. Hal ini disebabkan karena unsur hara yang ada di dalam tanah cukup untuk kebutuhan tanaman, sehingga proses metabolisme dan fotosintesis dapat berlangsung cepat serta hasil dari fotosintesis tersebut dapat disimpan di organ-organ tanaman. Menurut Lakitan (2011) berat kering merupakan bahan tumbuhan setelah seluruh air yang terkandung didalamnya dihilangkan dengan cara dipanaskan dengan suhu 800C selama 2 hari.

\section{Kondisi Abiotik Terukur}

\section{a. Derajat keasaman (pH) Media}

Pengukuran $\mathrm{pH}$ media tanam dilakukan sebelum diberi pupuk dan setelah diberi pupuk, adapun $\mathrm{pH}$ media tersebut dapat dilihat pada Tabel 7. berikut:

\begin{tabular}{|c|c|c|}
\hline perlakulan & pH sebelun diberi pupuk & pH setelah diberi pupuk \\
\hline $\mathrm{K}_{0}$ & 6 & 6 \\
\hline $\mathrm{A}_{1}$ & 6 & 6 \\
\hline $\mathrm{A}_{2}$ & 6 & 7 \\
\hline $\mathrm{A}_{3}$ & 6 & 6 \\
\hline $\mathrm{A}_{4}$ & 6 & 7 \\
\hline $\mathrm{A}_{5}$ & 6 & 6 \\
\hline
\end{tabular}

Tabel 7. pH Tanaman Sebelum Dan Setelah Diberi Pupuk

Keterangan:

$\mathrm{K} 0=\mathrm{Kontrol}(2,5 \mathrm{Kg}$ tanah $)$

$\mathrm{A} 1=$ Kompos $0,125 \mathrm{~kg}$, tanah 2,375 Kg

$\mathrm{A} 2=$ Kompos $0,25 \mathrm{~kg}$, tanah $2,25 \mathrm{Kg}$

$\mathrm{A} 3=$ Kompos $0,5 \mathrm{Kg}$, tanah $2 \mathrm{Kg}$

A4 $=$ Kompos $0,75 \mathrm{Kg}$,tanah $1,75 \mathrm{Kg}$

A5 $=$ Kompos $1,0 \mathrm{~kg}$,tanah $1,5 \mathrm{Kg}$
Tabel 7 menunjukkan bahwa pH media tanam sebelum diberi pupuk dan setelah diberi pupuk berada dalam kisaran netral yakni 6-7. Menurut Rukmana (2010) kisaran $\mathrm{pH}$ yang baik sebagai syarat tumbuh anaman bayam cabut adalah 6-7. Derajat keasaman $(\mathrm{pH})$ sangat penting bagi pertumbuhan tanaman bayam cabut, menurut Rukmana (2010) bila $\mathrm{pH}$ tanah di atas 7 pertumbuhan daundaun muda (pucuk) akan memucat putih kekuningkuningan (klorosis) akibat ketersediaan unsur nitrogen, besi, mangan, borium dan tembaga relatif sedikit.

Sebaliknya pada $\mathrm{pH}$ dibawah 6 pertumbuhan tanaman bayam cabut akan menurun akibat unsur fosfor, kalium, belerang, kalsium dan magnesium menurun dengan cepat. Terjadinya kelainan pada tanah yang memiliki $\mathrm{pH}$ di bawah 6 karena unsur alumunium, besi dan mangan merupakan racun bagi tanaman tersebut.

\section{b. Suhu Lingkungan}

Adapun rerata hasil pengukuran suhu lingkungan tersebut dapat dilihat pada Tabel 8. berikut:

\begin{tabular}{|c|c|c|}
\hline $\begin{array}{c}\text { Pagi hari } \\
\text { (pukul 06.30 WIB }\end{array}$ & $\begin{array}{c}\text { Siang hari } \\
\text { (pukul 12.30 WIB) }\end{array}$ & $\begin{array}{c}\text { Sore hari } \\
\text { (pukul 16.30 WIB) }\end{array}$ \\
\hline $27^{\circ} \mathrm{C}$ & $32^{\circ} \mathrm{C}$ & $25^{\circ} \mathrm{C}$ \\
\hline
\end{tabular}

Tabel 8. Rerata Suhu Lingkungan Tempat Pemeliharaan Tanaman Bayam Cabut (Amaranhtus tricolor L.) 
Tabel 8 menunjukkan rerata suhu lingkungan tempat pemeliharaan bayam cabut. Menurut Anonim (2011) suhu lingkungan yang optimum untuk tanaman bayam cabut berkisar antara 16-200C. Berdasarkan hasil penelitian diperoleh suhu lingkungan berkisar antara 25-320C. Suhu tersebut sebenarnya kurang optimum untuk pertumbuhan bayam cabut, namun ternyata pada kisaran suhu tersebut tanaman bayam masih dapat tumbuh dan berkembang dengan baik, hal ini berarti kisaran suhu yang diperoleh dari hasil penelitian masih dapat digunakan untuk pertumbuhan bayam cabut.

Menurut Dwijoseputro (1994), suhu yang rendah akan menghambat kerja enzim dan gen, sedangkan pada suhu yang tinggi akan merusak tanaman serta dapat menyebabkan laju transpirasi meningkat.

\section{c. Kelembaban Udara}

Adapun rerata hasil pengukuran kelembaban udara tersebut dapat dilihat pada Tabel 9.berikut:

\begin{tabular}{|c|c|c|}
\hline $\begin{array}{c}\text { Pagg hari } \\
\text { (pukul 06.30 WIB }\end{array}$ & $\begin{array}{c}\text { Siang hari } \\
\text { (pukul 12.30 WIB) }\end{array}$ & $\begin{array}{c}\text { Sore Lari } \\
\text { (pukul 16.30 WIB) }\end{array}$ \\
\hline $80 \%$ & $50 \%$ & $70 \%$ \\
\hline
\end{tabular}

Tabel 9. Rerata Kelembaban Udara Tempat Pemeliharaan Tanaman Bayam Cabut (Amaranthus tricolor L.)

Pada kondisi tanah dan udara yang lembab sangat berpengaruh baik pada tum- buhan. Kondisi lembab menyebabkan banyaknya air yang diserap ke dalam tanaman sehingga mendukung aktivitas pemanjangan sel-sel. Kelembaban yang optimum untuk pertumbuhan bayam cabut adalah $40-60 \%$ (Anonim, 2011).

Berdasarkan hasil penelitian rerata kelembapan udara tempat pemeliharaan bayam cabut berkisar antara 50-80\%. Kelembapan tersebut masih dianggap sesuai dengan syarat pertumbuhan bayam cabut itu sendiri karena pada kisaran kelembaban tersebut bayam cabut masih dapat tumbuh dengan baik.

Menurut Cahyono (2003) kelembaban udara yang lebih dari 90\% berpengaruh buruk terhadap pertumbuhan tanaman, yakni tanaman tumbuh tidak sempurna, tanaman tidak subur serta kualitas daun akan jelek. Sebaliknya jika kelembaban terlalu rendah akan menyebabkan kenaikan suhu dan dehidrasi pada tanaman.

\section{KESIMPULAN DAN SARAN}

\section{KESIMPULAN}

1. Pertumbuhan Bayam Cabut (Amaranthus tricolor L.) dengan pemberian komposis kompos berbahan dasar daun Krinyu (Chromolaena odorata L.) dan tanah menunjukkan hasil yang baik.

2. Komposisi pemberian pupuk kompos berbahan dasar daun Krinyu (Chromolaena 
odorata L.) dan tanah yang efektif untuk pertumbuhan Bayam Cabut (Amaranthus tricolor L.) adalah pada perlakuan A2 (Komposisi kompos 0,25 kg dan tanah $2,25 \mathrm{~kg})$.

\section{SARAN}

1. Perlu adanya penyampaian informasi kepada para masyarakat khususnya petani bahwa pemanfaatan kompos berbahan dasar daun Krinyu (Chromolaena odorata L.) dengan komposisi kompos $0,25 \mathrm{~kg}$ dan tanah 2,25 kg dapat meningkatkan pertumbuhan tanaman sayuran terutama bayam cabut.

2. Hasil penelitian ini diharapkan dapat diterapkan di dalam proses belajar mengajar serta dapat menjadi alternatif belajar Biologi di SMA kelas XII pada materi pembelajaran pertumbuhan tanaman.

\section{DAFTAR PUSTAKA}

Anonim. 2011. http://koperasitanituwed. blogspot.com/2011/12/budidaya-tanamanbayam.html . Diakses pada tanggal 30 november 2011.

Cahyono, Bambang. 2003. Tekhnik dan Strategi Budidaya Sawi Hijau. Yayasan Pustaka Nusantara: Yogyakarta.

Dwidjoseputro. 1994. Pengantar Fisiologi Tumbuhan. Gramedia: Jakarta.
Irwanto.2010.“Pemupukan”.http://pengertiandefinisi.blogspot.com/2010/10/ pemupukan.html. Diakses pada tanggal 17 November 2011.

Kastono, Dody. 2005. “Tanggapan Pertumbuhan dan hasil kedelai hitam terhadap penggunaan pupuk organik dan biopestisida gulma siam (Chromolaena odorata L) “. Jurnal Ilmu Pertanian. Vol 12 No.2. . 2011. Dasar- Dasar Fisiologi Tumbuhan. Rajawali Press: Jakarta.

Lingga dan Marsono. 2008. Petunjuk Penggunaan Pupuk. Penebar Swadaya: Jakarta.

Lakitan, B. 1996. Fisiologi Pertumbuhan dan Perkembangan Tumbuhan.PT Raja Grafindo Persada: Jakarta.

Prawirodiputra. 2007. "Krinyu ( Chromolaena odorata) RM king dan $\mathrm{H}$ robinson: Gulma padang rumput yang merugikan”. Vol. 17 No.2.

Rukmana, Rahmat. 2010. Bayam. Penebar Swadaya: Jakarta.

Simamora, Suhut dan Salundik. 2006. Meningkatkan Kualitas Kompos. Agromedia Pustaka: Jakarta. 